\title{
El escándalo de las nimiedades ${ }^{A}$
}

\section{Germán Colmenares}

\section{[Reseña y comentarios]}

El periodista Arturo Abella ${ }^{\mathrm{B}}$ monta un sainete un poco macabro con las víctimas de la revolución de 1810 . Vemos correr afanosamente a los próceres en esos días memorables para procurarse la protección de los de los gobiernos sucesivos, denunciarse unos a otros en el momento de ajustar cuentas, dirigir memoriales en que tratan de justificar inútilmente su conducta, o hacer valer una traición inconsciente a la causa republicana, para demostrar su adhesión al rey y su condición de fieles vasallos. Otros, menos visibles, buscan simplemente algún provecho ilícito que se les ofrece con el despojo de las víctimas de cualquier causa. Asombrosa en este caso la insignificancia de los gajes y la mediocridad de la ambición. Pero Abella busca deliberadamente las cosas pequeñas, casi de manera simbólica. El lenguaje excesivamente familiar sugiere el comadreo, y la malicia o la sugerencia velada penetran allí donde el investigador no tiene acceso.

"Dónde andarían las gargantillas de perlas que la virreina usó en las recepciones" (p. 329). Las volvemos a encontrar en la pág. 82 en donde “... se ata de nuevo el hilo de las gargantillas al proceso político en mejores condiciones". Se trata sin duda de las condiciones que requieren los hábitos de un periodista para emular a Alejandro Dumas o, en instantes de seriedad y altura, el relato "verídico" de las andanzas de Cagliostro en torno a la romántica figura de una reina desvalida aunque un poco ligera. La tentación de ser leído es mucho más fuerte en un periodista que la simple

A En Eco. Revista de la Cultura de Occidente, tomo XIII, n. ${ }^{\circ} 76,4$, agosto de 1966, 448-451. Reseña de Arturo Abella, Don Dinero en la Independencia (Bogotá: Ediciones Lerner, 1966).

B Arturo Abella fue un periodista y presentador de noticieros de televisión, con inquietudes intelectuales de historiador - en realidad era un cronista de chismes y enfrentamientos personales entre "patricios" de la independencia-, que lograba tener un auditorio y captar la atención de los lectores bogotanos de nivel cultural y concepciones similares a las suyas. Uno de sus oponentes de época fue Abelardo Forero Benavides, político liberal, historiador y profesor universitario de renombre, cuyas concepciones de la historia y del "papel de los individuos" eran similares a las de Abella. Nadie recuerda hoy, con toda razón, a Arturo Abella, y es difícil que en el presente un joven estudiante de Historia pueda tener noticia de su pequeña obra. Un autor actual con mucha semejanza con Abella puede ser el político y periodista de radio Alberto Casas Santamaría, que también escribe obras de historia de cierto éxito - véase por ejemplo Alberto Casas Santamaría, Memorias de un pesimista (Bogotá: Intermedio, 2020)—, con la diferencia de que Abella era un "cachaco" pobre, que murió en pobreza extrema. Uno puede preguntarse por qué Colmenares, que reseñaba en Eco obras como Civilización material, economía y capitalismo de Fernand Braudel, se preocupaba por trabajos como los de Arturo Abella. En realidad era una tarea que tenía importancia, dada la escasa afirmación en el país de un saber histórico medianamente riguroso y la aceptación que lograba ese tipo de crónicas, exactamente como hoy la atención de la opinión lectora de obras de historia no prefiere las obras de los historiadores universitarios, sino más bien las de los Arturo Abella de hoy: Diana Uribe, el mencionado Alberto Casas, el propio Antonio Caballero, y varios otros. 
preocupación por la verdad. Además, basta tomar a un lector desprevenido para crear la ilusión de veracidad aunque solo sea por el espacio de un solo día. O crear cualquier ilusión cuando se echa mano de un objeto literariamente simbólico, el collar de la reina o las gargantillas de la virreina, para enhebrar una trama novelesca. La sombra de Stefan Zweig se pasea desvanecida y caricaturesca hasta la pág. 188, cuando las gargantillas se mencionan por última vez para concluir el libro.

La obra se refiere muy poco — o casi nada - a circunstancias económicas que puedan darnos la imagen racional de un proceso histórico. "Don Dinero", el protagonista de la historia y el objeto de la codicia de personajes vagamente balzaquianos, se ve reducido a objetos casi sin valor que figuran en los archivos apenas como un testimonio de la meticulosidad burocrática. ¿Qué quiere probar el autor? Acaso que los hombres se aficionan más por un chaleco dorado que por una palabra demasiado sonora. O que las palabras sonoras se emplean para disimular una mediocridad inevitable. Pero se puede escribir una historia de la mezquindad de los hombres de una manera tan ineficaz como una historia de sus sueños. En ninguno de los dos casos podría probarse que el hombre sueña constantemente o que siempre es mezquino. En este caso la parcialidad salta a la vista puesto que al autor no se preocupa por matizar siquiera la ruindad de sus personajes. Nariño o Santander o Zea presentan la misma imagen convencional del caballero de industria, a veces afortunado y a veces sin suerte, pero víctima siempre de sus propios embrollos. En el caso de Nariño se alcanza a sugerir un parecido dudoso con "Los negocios del señor Julio César" de Brecht, aunque el autor trata de convencernos de que sus fuentes no son puramente literarias sino que tienen un apoyo documental. Podemos hacer una reserva en todo caso en cuanto a la inspiración, que proviene, sin lugar a dudas, de Zweig, Dumas y Brecht.

Puede parecer encomiable la intención de amenidad que sugiere una comparación irreverente con obras literarias de algún valor. Pero como el libro se presenta como una obra de interpretación histórica, debe reprochársele al menos que el autor no se preocupe en ningún momento por algunas exigencias críticas que impone toda ciencia.

La mezquindad o el egoísmo son inclinaciones humanas cuya eficacia explicativa de un acontecer histórico es tan escasa como la de las más altas virtudes. Y aun si admitimos que los hechos están subordinados íntegramente a la voluntad maliciosa o bien intencionada de algún personaje, no debe perderse de vista que los testimonios que se refieren a las virtudes o a sus vicios suelen ser igualmente arbitrarios. Sin duda alguna ningún personaje histórico está exento de flaquezas. Puede inclusive poseerlas en abundancia. Pero nada justifica la preocupación exclusiva de ponerlas en relieve, recogiendo con acuciosidad todos los chismes a que han dado lugar. Aunque la maledicencia esté consignada en documentos, esa circunstancia no presta un ápice de respetabilidad a su naturaleza. No se trata siquiera de una regla de decoro para un escritor, aunque la afición excesiva por los chismes históricos pueda mostrarnos una 
ocupación histórica curiosa. Es objetable, en cambio, ensartar tales chismes uno a uno como punto de referencia de hechos históricos puesto que la conexión con estos hechos es puramente accesoria aunque resulta muy fácil exagerarla. Establecidas dos series de hechos contemporáneos puede improvisarse a voluntad una relación arbitraria y deformar deliberadamente la óptica con respecto al pasado para que la serie meramente accesoria se convierta en la clave principal.

Este procedimiento engendra el panfleto histórico que no es, ni mucho menos, un género nuevo. Nadie ha intentado nunca, sin embargo, emplearlo como una fuente de información objetiva, sino más bien como un testimonio de la condición desusual de una sociedad. No constituye una perspectiva sino una deformación consciente de la historia que obedece a la miopía o a la mala fe. En este caso nos inclinamos a pensar que se trata de la intrusión inofensiva, aunque mal intencionada de un periodista que juzga provechoso el escándalo por una inclinación profesional. 